\title{
STUDENTS' SPEAKING SKILL INMEDICAL ENGLISH SUBJECT AT MIDWIFERY STUDENTS
}

\author{
Pipit Rahayu' ${ }^{1)}$, Rosi Lestari ${ }^{2)}$ \\ darariau2010@gmail.com,rosilestari2806@gmail.com \\ Faculty of Teacher Training and Education, University of Pasir Pengaraian
}

\begin{abstract}
This purpose of the research was to find out students' speaking skill in midwifery students at third semester students of midwifery program in university of Pasir Pengraian. The kind of this research was descriptive qualitative only focus describing the data. The data got from documentation speaking practice of medical English. The researcher took the data from documentation video. In collecting the data the researcher used documentation and speaking test to got the data. In analyzing the data the researcher used the components of speaking such as : pronunciation, grammar, vocabulary, fluency and comprehension. The population of the research was third semester students academic 2018/2019 Midwifery Study Program, the sample of this research were 14 students. Based on the result of analysis, the researcher found 1 student (7\%) had good score, 5 students $(36 \%)$ had average score and 8 students $(57 \%)$ had fair score.
\end{abstract}

Key Word : Speaking skill, Medical English, Midwifery Students.

\section{INTRODUCTION}

Speaking is a communicative way to learn English because it always uses in communication. According to Tarigan in Melyaningsih (1981:15) the main point of speaking is for communicating, so we have to convey the thinking and feeling effectively and the speaker must understand the meaning to be communicated in order to make other people understand with what they are talking about. By mastering speaking, the students also can do conversation meaning, receiving, and processing information to others directly.

In University of Pasir Pengaraian not only for English study Program, English is learnt by all of students in each study programs that are available, especially in midwifery study program. The students were not familiar and some of them were not always speak English, they could not produce some words or 
sentences, because difficult to memorize or lack of vocabulary. Some students also difficult in pronouncing English words and they did not understand completely when their friends talk to them. Further this article report about "How is students' speaking skill in midwifery study program at University of Pasir Pengaraian?"

\section{REVIEW OF RELATED LITERATURE}

There are some experts who give definition about speaking. According to IIrawati (2014: 26) defines speaking as an activity to produce sayings in the form of words and sentences orally in order to communicate with others. In other word, Jordan (2009:3), states that speaking is the action of delivering information or expressing someone thought and feeling in spoken language. Moreover speaking is an interactive process of constructing meaning which is comprised of producing and receiving information (Brown, 1994; Burns \& Joyce, 1997). According to Rahayu (2012) Speaking shows capability to use a language. Therefore good speaking is when someone have a good capability to use language. In addition Nunan (2003:48) mention that speaking is a productive skill which consist of systematic verbal utterances that carry out meaning.

Midwifery students in university of Pasir Pengaraian learn Medical English subject by using book From Annie Perwata and Anik Maryunani (2008) "English For Midwives" there are some topic must be learn by Midwifery students at university of Pasir Pengaraian Sexual reproduction in human, Sex organ of the human male, Sex organ of the human female, Sperm, Sperm production, Egg formation I, Egg Formation II, Evolution, some disease, Fertilization, The mysterious process, Pregnancy I, Pregnancy II, The placenta, Another mystery, Group work, More group work, The system of the baby, The unsolved mystery, and The last session.

\section{RESEARCH METHODOLOGY}

This research was design a descriptive quantitative research. According to Arikunto (2010) say that the descriptive research is the research have purpose to accurate the situation, condition, and other which is said, the result is explained in report of the research. This research consist of one variable and it was design using descriptive quantitative method.

\section{FINDING AND DISCUSSION}

\section{Students' speaking skill in midwifery study program}

There are some components of speaking based on the Arthur Hughes theory. The components are pronunciation, vocabulary, grammar, fluent and comprehension. 
Table 4.1 the analysis on the students' Pronunciation

\begin{tabular}{|c|c|c|c|}
\hline No & Range & Frequency & Percentage \\
\hline 1 & $81-100$ & 0 & $0 \%$ \\
\hline 2 & $61-80$ & 0 & $0 \%$ \\
\hline 3 & $41-60$ & 2 & $14 \%$ \\
\hline 4 & $21-40$ & 7 & $50 \%$ \\
\hline 5 & $0-20$ & 5 & $36 \%$ \\
\hline & Total & 14 & $100 \%$ \\
\hline
\end{tabular}

Based on the table above, it can be seen that the students' level in pronunciation of speaking can be seen that students who got excellent and good level was $0 \%$ students who can categorized as the average level was $14 \%$ number of students who can categorized in the fair level was $50 \%$ and students can be categorized in the poor level was $36 \%$. It means that the students' pronunciation in speaking as fair level.

Table 4.2 The analysis on students Grammar

\begin{tabular}{|c|c|c|c|}
\hline No & Range & Frequency & Percentage \\
\hline 1 & $81-100$ & 0 & $0 \%$ \\
\hline 2 & $61-80$ & 1 & $7 \%$ \\
\hline 3 & $41-60$ & 3 & $21 \%$ \\
\hline 4 & $21-40$ & 10 & $72 \%$ \\
\hline 5 & $0-20$ & 0 & $0 \%$ \\
\hline & Total & 14 & $100 \%$ \\
\hline
\end{tabular}

The frequency level in grammar of speaking can be seen that students who got excellent $0 \%$ students who can categorized as good level was $7 \%$ number of students who can categorized as the average level was $21 \%$ students who can categorized in the fair level was $72 \%$ and students can be categorized in the poor level was $0 \%$.

Table 4.3 the analysis on the students' Vocabulary

\begin{tabular}{|c|c|c|c|}
\hline No & Range & Frequency & Percentage \\
\hline 1 & $81-100$ & 0 & $0 \%$ \\
\hline 2 & $61-80$ & 3 & $21 \%$ \\
\hline 3 & $41-60$ & 4 & $29 \%$ \\
\hline 4 & $21-40$ & 7 & $50 \%$ \\
\hline 5 & $0-20$ & 0 & $0 \%$ \\
\hline & Total & 14 & $100 \%$ \\
\hline
\end{tabular}

The frequency level in Vocabulary of speaking can be seen that students who got excellent was $0 \%$ students who got good level was $21 \%$ students who can categorized as the average level was $29 \%$ students who can categorized in the fair level was $50 \%$ and students can be categorized in the poor level was $0 \%$

Table 4.4 the analysis on the students' Fluency

\begin{tabular}{|c|c|c|c|}
\hline No & Range & Frequency & Percentage \\
\hline 1 & $81-100$ & 0 & $0 \%$ \\
\hline 2 & $61-80$ & 0 & $0 \%$ \\
\hline 3 & $41-60$ & 7 & $50 \%$ \\
\hline 4 & $21-40$ & 7 & $50 \%$ \\
\hline 5 & $0-20$ & 0 & $0 \%$ \\
\hline \multicolumn{2}{r|}{ Total } & 14 & $100 \%$ \\
\hline
\end{tabular}

Based on the table above, it can be seen that the students' level in fluency of speaking can be seen that students who got excellent and good level was $0 \%$ students who can categorized as the average level was $50 \%$ number of students who can categorized in the fair level was $50 \%$. 
Table 4.5 the analysis on the students' Comprehension

\begin{tabular}{|c|c|c|c|}
\hline No & Range & Frequency & Percentage \\
\hline 1 & $81-100$ & 0 & $0 \%$ \\
\hline 2 & $61-80$ & 1 & $7 \%$ \\
\hline 3 & $41-60$ & 3 & $21 \%$ \\
\hline 4 & $21-40$ & 10 & $72 \%$ \\
\hline 5 & $0-20$ & 0 & $0 \%$ \\
\hline & Total & 14 & $100 \%$ \\
\hline
\end{tabular}

Based on the table above, it can be seen that the students' level in comprehension of speaking can be seen that students who got excellent level was $0 \%$ students who got the good level was $14 \%$ students who can categorized as the average level was $43 \%$ number of students who can categorized in the fair level was 36\% and students who got in poor level was $7 \%$.

Table 4.6 Percentage of total score students' speaking skill

\begin{tabular}{|c|c|c|c|}
\hline No & Range & Frequency & Percentage \\
\hline 1 & $81-100$ & 0 & $0 \%$ \\
\hline 2 & $61-80$ & 1 & $7 \%$ \\
\hline 3 & $41-60$ & 5 & $36 \%$ \\
\hline 4 & $21-40$ & 8 & $57 \%$ \\
\hline 5 & $0-20$ & 0 & $0 \%$ \\
\hline \multicolumn{2}{|c|}{ Total } & 14 & $100 \%$ \\
\hline
\end{tabular}

The finding showed that of the result students' speaking skill in speech, there were 1 students had percentage $7 \%$ in the range between "61-80". There were 5 students had percentage $36 \%$ in the range between "41-60". There were 8 students had percentage $57 \%$ in the range " $21-40$ ". It means that the result of speaking test in speech was in average score of
38.63 and it can be categorized as Fair Level.

\section{CONCLUSION SUGGESTION}

AND

Conclusion:

Students' difficult in speaking by students' midwifery study program it cause the students not have much time to learn English, the students never speak English in their daily activities, the students felt difficult to understand study English, the students difficult speak English, the students felt difficult in grammar, the students difficult to pronoun, the students limited vocabulary and the students not fluent in speak English.

Suggestion:

1. For the lecture

a. The lecture must give more attention to improve students speaking skill in medical English practice.

b. The lecture must be pay attention students' problem when teach speaking skill.

c. The lecture must be more detail explanation in speaking skill.

d. English teacher must be invite more the students to use English language.

2. For students

a. The students should be pay attention to the lecture explanation.

b. The students should be more study in speaking practice 


\section{ACKNOWLEDMENT}

I would like to say thank you Evi Kasyulita, M.Pd and Pipit Rahayu, M.Pd as my advisors for enhancing my spirit, giving support, a great help and contribution of knowledge to complete my thesis.

\section{BIBLIOGRAPHY}

Arikunto, (2010).Prosedur Penelitian: Suatu Pendekatan Praktik. Jakarta: Rineka Cipta

Brown, H. D. (2000). Teaching by Principles. Cambridge University Press.Continuum.for the EFL Learners in Chine.

Hughes, Arthur. (2003).Testing for Language teachers (Cambridge University),131.

Melyaningsih, I.A.(2015). Presented as Partial Fulfillment of the Requirements for the Attainment of the Sarjana Pendidikan Degree in the English Language Education. University of Yogyakarta.

Perwata, A \& Maryuni, A. (2008). English For Midwives. Jakarta.

Nunan, David. 2005. Practical Engllish Language Teaching Speaking. Singapore: The McGraw - HillCompanies, Inc.Pedagogy. San Francisco: Longman Inc.Press.
Rahayu, Pipit. (2012). Improving Speaking Skill Through Negotiated Materials Based on Current Syllabus at Grade XI Accounting of SMK.N 1 PasirPengaraianRokan Hulu Riau. JurnalPendidikan. Vol. 1 No 1.

Sugiono, (2009). Metode Penelitian Kuantitatif Kualitatif dan R\&D.Bandung. Alfabeta

Surip haryani, (2018). Designing atwork-conversation based materials for diploma iii midwifery program. Stikes Madani Yokyakarta

Vanderkevent.1990. Teaching Speaking and Component of Speaking. New York.

Widoyoko, EkoPutro. (2012). Teknik Penyusunan Instrument penelitian. Yokyakarta: Pustaka Pelajar. 
Balnk Page 